\title{
The Great Romance: a science fiction/utopian novelette.
}

\author{
Dominic Alessio
}

[Note: Volume One of The Great Romance was published in the previous number of Kotare. Volume Two is reproduced below. Although the story is clearly unfinished, it is not known whether any further volumes were ever written or printed, or if so, whether they have survived. The next number of Kotare will include a discussion of the significance of The Great Romance in the context of nineteenth-century science fiction writing and utopian fiction. In the text below, obvious typesetting and similar errors have been silently corrected.]

\section{CHAPTER XIII. \\ Preparing to start-suspicious thoughts.}

From fruit to flower-from the deep dale to the treeladen forest-from mountain to sea-from rivers of bright water to the desert ground-we wandered and searched, like children on a holiday, ever eager to see, to know, and to discover, and perhaps I, John Hope secretly feared to meet that hour when Moxton and Weir would leave me alone on the planet and again tempt the dangers of the great deep.

But the dreaded hour ever comes swiftly; pleasure makes wings for time, and but for memory it would be worth while to follow life's trail through the desert of existence for all the golden hours and bright oases which we can see; but memory-memory gives again and again each happy thought, each celestial moment thrills its thousand times through all our heart, brightening life's dullest hours.

So, now our holiday was past, why in truth, with so great a deed accomplished, should Weir and Moxton longer stay? Everything that I could want for years to come was stored in my little castle, which, though small, was yet formidable in its powers of defence, and in the journeyings, which day by day we accomplished, nothing had we seen capable of hurting man, or in any way coping with his sure and terrible arms. There were, indeed, huge lion-like animals which moved under leaders, and worked together like an army, but they never left their native forest, and these seemed the most formidable, roaming without check through a large part of the world. 
We had selected a spot some hundreds of feet above the common level, for here all the water seemed land-locked, standing like inland lakes at all sorts of heights, rising and falling, with the seasons, and with no general intercommunication. It was a fine sweeping plain within the tropics, but kept cool by its elevation, and by the fact that on the still higher ground spread a large lake. There were a few trees scattered here and there, sometimes in clumps, sometimes almost deepening into a coppice, and under a near group I had a large tent fixed for comfort in the warmer weather.

Yet, despite the want of apparent danger, and the complete reign of brute strength, there was in all our minds a strange dread and uneasiness at parting, and indeed we surely needed to leave a large margin for possibilities in reckoning the coming years, for should aught happen on their homeward voyage, might they not be whirled away on their unprecedented course till they became but a mite of senseless matter gripped in the undying hand of fate; and who then should be mourned-they or I, a solitary being in a lonely world? Yes, I might for ages carry on that awful existence; I felt even as though it had already begun, hoping from long year to year that another vessel would tempt that wondrous deep from which no travellers had as yet returned-hoping_but ah! how vainly_hoping to see again those glorious beings which woke me from my wondrous sleep; hoping-ah! hope is never the word for that infinite yearning - to see her but again-it seemed worth a century of life-to hear those gentle words, to feel the least breath of that love which was beyond all pity or compassion.

Moxton, and her brother, too, their hearts seemed clouded and confused to me, and the sleeping devil which had seemed to live beneath Moxton glared as when I first knew him, returned like a dream to trouble my brain, and with it many fearful thoughts. For was not I an alien, an outcast, and had not I presumed to wed myself to the future in defiance of fate and law? Then, as I had done so much-led the van in the battle of force against brute matterhad not this people, this council of nations, carried out well their unwritten commandments, and given me by my own choice their highest sepulchre, their widest tomb?

The men, too, whom I had chosen, or who had chosen me - was there not a fitness - her brother, who would have been wronged in his sister's unionand Moxton, did not her image dwell deep in his heart? aye, deeper perhaps than I could fathom-by the world judged, by my own conscience condemned-and these two men, though I believed they loved me as brothers-my fitting executioners? Yes, what kind cruelty! I could wander at large in my tomb; I could live till time itself grew gray, yet could never again mingle with the perfection of the future, or see the wondrous light in those 
faces now lost to me. Yes, this was why they lingered, and walked apart; why a cloud had settled over those great spirits which I was but beginning to leave.

I was sitting and thinking in my lonely castle, the Star Climber lay resting on the ground some hundreds of yards away, and I saw Weir and Moxton returning through the lengthening shadows. I could but fancy their minds, but in fuller comradeship than I had ever known with them; yet, as they grew nearer, that tide of unhappy thought went back, a stronger manhood seemed to be asserting itself, till it was as though my brain-so long ago benumbed in that wondrous sleep-was but awakening; as though the delicate fibres of sense had been so near dissolution, perhaps even touched with decay in those long dead years, that a horror as of death was always hanging over me, breeding fearful thoughts and strange fancies. Yes, I had known of one such unhappy case, where death had actually been, yet was the great conqueror driven out; the miserable man had died from bad air in some earth shaft, had been pronounced dead, and given over for burial, and so taken charge of by the savants of science, and after many hours had elapsed, revivified. But then the trouble began; he was not himself in the finer tissues and the brain, corruption had begun, and a terrible fear and horror always hung over himmore especially as regarded his friends. It was a fearful drama when his sons saw the once dead man again-himself, yet not himself, with the taint and fear of death always upon him. His recovery had not been made known to them, and it was only the strange instinct which drew-yet frightened-drew him by an awful fascination to his natal spot, that brought about the discovery and made the fact known to the world.

By this time Moxton and Weir were drawing nigh, and could not but move uneasily under all that sense of thought. They must have divined afar off all that tempestuous feeling, for Weir came, and laying his hand on my shoulder, said-"I shall bring back my sister, Hope, as surely as I reach the earth; those thoughts that trouble you are, as you know, but a nightmare, as far from the truth as from your latter self."

And Moxton, looking at me with a face that would have made doubt die of shame, said-"If I liked the girl as much as you do, Hope, I would send her to you and seek to find some other, because I know how much she likes you. You must not think because once her image dwelt awhile in my mind no other can grow there. I think there are thousands whom you would have loved had they been brought near you, and you know our present lives have wider instincts, and are more in unison with all nature and one another."

They both knew better than I could tell them that all these thoughts were but as dreams, though fated perhaps to be dreamt during the night of their departure, and only to be thoroughly done away by the morn of their recoming. 
The few last days came swiftly. We all collected fruits, flowers, and the smaller animals, to be taken back. There was not much in the way of utility, but for beauty, variety, strangeness-both beast and bird, fruit and flower, were endless.

The new air of the planet conspired to give life and vivacity to every act, and because we liked these days they seemed the faster to flee away, for both Moxton and Weir dreaded the months of monotony to come. Almost a fear seemed to hang over them as the hour of departure drew nigh-not for themselves, but for me.

"There is no doubt we were fools," said Weir, "to arrange to leave you here. There may many things happen in this planet which we know nothing ofeven the beasts have almost sense enough to besiege you. If I were you I should not travel except in the air. You are quite safe in that little boat, and even when you are about here I would always keep my revolver in my handmake a habit of it. I don't know what we would do if, when we came back, we found anything wrong with you; it would spoil the spirit of the whole enterprise; to us it would hardly be a success. I think there are animals we have not seen, four-footed men, perhaps, as cunning and as cruel as the most ancient savage. There is certainly not much to attract anything here except grassfeeders, but you know the grass-feeders are themselves food."

I promised duly to take care of myself, and, indeed, intended to do so, for life was dear to me as ever.

Early morning was the time appointed for their leavetaking; then the planet would bring us round to the appointed place, and the Star Climber once more dash away on her heavenly route.

We spent a large part of the night in preparing for the start, this needing nice calculation and accurate despatch; for although if they once came into the limits of the earth's attraction their erratic orbit and natural motion would bring them into the atmosphere, and so enable them to land, yet, were they so far out as to miss the short circle, then, indeed, God knows whither they might wander. Might they not, like other lost travellers, lose not only the way but the sense to re-find it, and if not stopped by one of the outer planets, go out into an abyss more dread than that of the dyspeptic's dream? But these were all foolish visions, founded on nought, for we were dealing with real facts and certainties, and not more surely have summer and winter, and day and night, followed without alteration or accident, than that if started truly on our course we should follow it and arrive at its end. We had, however, decided to start the Star Climber by a different method. Instead of circling round to attain speed, and then going in the direction as the ship moved outwards towards space by steering or wing power, Moxton determined to poise the Star Climber in the air, keeping her steady and motionless with her lesser vibratory motion, till, 
like a rifle or telescope, she was accurately sighted, then discharge, as we had done in the Magellan cloud, our rearward artillery-this would give her a swift and true start, with about three times the speed with which we left the earth; besides which, they would still have the ten miles of atmosphere to correct any slight error, and all their wing power to accelerate their already swift motion.

\section{CHAPTER XIV.}

\section{Dream-new inhabitants.}

The broad sun was throwing his misty beams over the dew-laden planet. We had shaken hands; we had parted. I stood on the grassy turf, Moxton and Weir on the flying vessel. "Once more, Weir, good-bye ! good-bye !" Stern time never yet tarried. With waving hands and lingering looks they were gone. The huge lids of the vessel that had till now lain open, began to rise and slowly fold them within their air-tight clasp. Weir appeared again for a moment at the lesser door, then that, too, was closed, and for an instant all was silent. Then the long wings stretched themselves out and began to move with a short, rapid motion, quickening, till the grass and herbs beneath were beaten from the ground by the fiercely-driven air, and as those wing points grew into a blue haze the grand vessel lifted herself up, steadily moving away from me till well nigh a mile distant.

I did not wish to be left stunned with the noise of her departure. Again I saw her poise herself steadily. Gradually the fore part rose from the level plane till the vessel hung steadily at an acute angle with the planet's surface. This, as in their start from the earth, would give some twelve miles of pretty dense atmosphere to travel in before the thinner air was reached. I knew the minute was drawing near. I saw the ship move slightly, and then seem fixed like a falling tower across the firmament without even a tremble or perceptible quiver. Then, at the appointed second, the stream of fire flashed out and the fearful deafening roar fell on my ear. I saw her rush, upwards, onwards, amid such a continuous thunder peal as this world certainly never heard before; like the evil angels of old, she left in fire and flame. Swift, like a gigantic meteor, she fled away; she hung for some seconds out over the horizon, then grew smaller and smaller, till like a point of light-a star-she vanished, and I-with half my dreams, half my hopes realised-stood alone on the new planet. Alone. Yes; though we had been here weeks, how strange the grass, how new each leaf! Each little unfamiliar flower lifted its eye to mine as though some angel whispered in its ear that I was alone, and it feared and wondered at me. 
Then I sank down on the grass and cried like a child, like a woman who knows the vanity, the sweetness of grief. I hid my face on the earth, although there was no eye to see. Then I grew calm. I recollect the breeze playing about my head, the warm sun striking down on me. Then consciousness faded-I wandered into the land of dreams, and there again I lay stretched, but out on a burning plain, an unutterable desert. I rise up; I look abroad, and there before me in the uncertain distance some thing with two colourless insect-like wings stood stiffly up, still as if dead, and still farther away another, and another. Measureless distance all around. Like dead infernal things do my thoughts speak them; and ere ever you come near them they rise and move away; and their wings have no motion; then stand again, still, silent, horribly certain. Is it a remnant of an unknown hell left here, where forgotten of all, unseen in the array of the eternal ages, they are tormented not; they wander no more, but flit, flit from all and stay here for ever? Then that grim vision faded, and a voice cried-"Herein is the prophecy-that thou should'st work among rotten wood, having an ass's tail for a sky scraper, and wanting both wit and money." I grew puzzled and confused; conscious again of the hot sun striking on me; then dimly, yet ever increasing with my returning senses, a second consciousness of some other presence, aye, no foot on the sand, but of beings standing over me-gods or angels, men or devils, what or who? The sense of their presence wrenched back my senses from the world of the brain's play-time, and brought at last to me the uses of my mortal vision. Strange beings! how shall I describe them? with no likeness to humanity except that they stood on two legs; with arms, yet not arms; faces human, yet how unlike!

I woke to the sense of their presence, to see them gazing down, arms linked to each other, male and female, gazing with soft eyes on my yet recumbent figure, their fine bodies covered with a down-neither of bird nor animal-soft and dark, and their heavy, lithe limbs, such as might have developed from that earliest of prehistoric elephant, had not the heat of a younger world debased him, and nature's giant youth pushed him in her recklessness to balk rather than serve.

They did not move as I awakened; they stood still as I leaned on my elbow, too crazed with wonder to speak, as drawn up by fascination I arose. I even advanced towards them. Then the smaller one shrank back, while the other lifted a limb into the air; but I spread out my two hands and I think my lips made unintelligible attempts to speak, but whether any words broke from them I do not know. I think my speech then dwindled into unintelligible mumblings, like those of an idiot, but the action was understood. Strange sounds they made; the huge limb descended; it touched my hands with a soft motion; then I stroked that extended arm; and impelled by those independent 
workings of the brain, I became emboldened and took the quaint ending of that limb in my hand, and shook it as I would a friend's hand. Then what was the laughter of the planet broke in motion over their faces, and moved in the air with a refreshing, peace-giving breath. It swept away my dread-a smile broke on my features - I went still nearer-I put an arm on each and laid my face against the face of the smaller one. Each motion of confidence was reciprocated; she inclined to me, touching me with a soft motion. Then we parted, and again looked at each other.

How strange it seemed-we could not speak. There was intelligence, knowledge, in every line of their features, and with low, strange voices they turned to each other and seemed to converse. "Will you come with me?" I said, and I think it was the first intelligible sentence I had uttered since I saw them. But as with assenting motions, and a low, sweet intonation that sounded to me like a repetition of my own words "come! come!" they turned to me. I led the way to my castle.

They would not enter. They stood a few yards from the door with their arms again linked around each other, and I could but think they were wise to use such prudence. I brought out of my stores what I could think of to please the eye or delight the palate. I spread these things on the grass and sat down beside them, beckoning them to do the same, and to eat and drink with me. They did this without fear, but so daintily and so delicately that I could but wonder how they supported life in those strong muscular bodies. Their little attentions to each other-like two lovers, or still more like two children playing at a feast-were so new and original, that I was occupied with but watching them. These were not savages, and how far removed from animals-over and above each kindly motion, each laughter-loving thought lit their eyes; how much sagacity they had needed to keep themselves hidden from our strange invasion, and how much courage to come so near to me when my companions left in such a chariot of fire and noise I could scarcely tell. Perhaps they had watched us day by day-had seen that cruelty and destruction were not the gods of our nature. I tried hard to begin to learn their words or signs, or to teach them mine, but each feature, each bone, each muscle was different, and I saw that it would be a work of time ere we could begin to form sounds which could be called imitation. When we rose up, they in their turn beckoned me, and I followed, or, rather, went with them; not, however, carelessly. I provided myself, besides the arms I always carried, with another revolver, whose explosive bullets would blow up a rhinoceros. I never needed them. Afterwards I thought almost with shame at my doubts concerning my gentle companions. They led me on, keeping up an occasional converse, beckoning and pointing often to me, but in such a way that I did not understand. They led me to the borders of the upland lake, and there under 
the tall herbage was a rude boat, or rather raft. They evidently wished me to embark with them, but to this I would not consent, and after a while they left me, promising, as far as signs could point, to return again.

\section{CHAPTER XV. \\ Further describes the inhabitants.}

I walked slowly back to my dwelling, drinking in the new ideas that had come with such a flood upon me, at every step.

More than the new world to me were these creatures, more than my long sleep and awakening, more than aught save those I had left on the earth. All through the evening and night were there strange figures and quaint patient faces relimning themselves again and again in my brain, till all this burden of knowledge and new experience seemed almost too much for me; these older memories should have been beneath the daisies, and younger heads and happier hearts have been unravelling these mysteries, but nature's great balm of sleep comes to us alike in palace and dungeon, lying near by to many friends, or in a world alone. It came to me in my lonely castle, deep and peaceful; nor did I wake till morning light.

Bright sunshine and dewy grass greeted me as I went out, and my thoughts turned at once to my companions of yesterday-to this new race. What should I call them? By what name should I think of them? Ah! how poorly I played the part of a second Adam in this new world. He named all the creatures, and I could not find a name for the first of them. But, then I thought of the star, the planet of love, and determined to call them by it, namely, Venus, and by that name they were afterwards known.

Scarcely need to say that I looked around to see if I could discover anywhere those quaint figures, or that I listened if I might catch the low murmurings of the Venus tongue, but nought could I see or hear of them. So I returned and rolled out my little boat, determined to find them.

My boat-the Midge she was called, and, perhaps, in the world I had left, never was there constructed a greater triumph of mechanical skill and beauty - as fair as a lady's finger, as glorious as an angel among the birds, by land, or air, or water. She could run, or fly, or swim. I got on board of her and took a preliminary canter through the fresh air, speeding on till the rushing wind seemed to take away my breath. Then I returned, closed up my castle, and went to seek the Venuses.

I was not long in reaching the upland lake on which they had launched; it stretched away large and clear before me, with long arms like bands of bright water running far up between the hills. But 'twas as calm and as lifeless as when, with Moxton and Weir, I had passed over it. The sedge and herbage 
were untrampled on the bank, and the fish sped away at my shadow. But I never doubted the Venuses would come. I never for an instant thought my vision of yesterday was a dream. I dropped down with the Midge contentedly into the water, watching the finny inhabitants of the deep, waiting contentedly in the morning sunshine. Nor had I long to wait, for soon upon one of the long, winding waves of water I saw them appearing, seemingly just starting on their day's voyage. I put the Midge in motion, and soon came near them.

How strange they looked! how uncouth to the eye now freed from excitement, yet not trained by familiarity, each with a rude paddle propelling the boat! But as they came near they shipped their oars, and began to greet me with bows and waving of the hands, with ununderstood, yet soft and pleasant voices.

"The Venuses." I kept repeating to myself the word each time I looked at them, as though it could in a manner explain their identity to me, or help me to class them among the beings I had known-but as Venuses, as new and strange beings, must they ever remain. This is what I seemed to be learning during my first interview with them.

With their consent I tied their raft to the Midge, and under their guidance we went back to find their home. Nor could I be sure what I should find, whether camp, or village, or solitary hut, but from their signs guessed the latter. Yet it could not be that they were enacting Eden in another world; they must surely have some cousins or aunts, or at least must have had a father or a mother. But presently, as we went farther up the fiord-like water, their solitary hut or nest appeared built on piles-out in the water, covered with grass and boughs, and only to be approached by coming along a row of stilt-like piles driven between it and the land.

We tied the boats to the posts and they invited me to enter. 'Twas a small mossy cabin, with a strange, bird-like air pervading it, but scrupulously clean, neat, and almost pretty, as if half a bird's instinct had been by some beneficent power bequeathed to them, but so small that, apart from the space occupied by the fruits and nuts which they had in store, there was hardly room for them to stretch themselves.

But were they indeed so completely alone? I thought and asked, as I looked out again and could see no sign of other habitations.

Was theirs indeed a semi-solitary existence? I could hardly think so while their low voices and pleasant laughter murmured and rippled in my ears. Yet, by signs, I gathered in reply that they were truly now alone-all others far away; and as I looked at their provisions I divined the reason-if they lived without tillage on the fruits of the ground, they must need be few in number, and live far apart. 
I ate of their provision, and from their motions, and as yet incomprehensible voices, began to see dimly new facts, which afterwards grew real and trustworthy.

Yet, after all, it was they who had to learn. Their mind in its best phases had little that was superior to humanity. Some happier thoughts—some sweet companionship_some feelings of freedom and pleasure-new perhaps to any inhabitant of my native world; yet of that great body of thought which has arisen from our mechanical and omniverous propensities, they knew nothing, and as I afterwards found out, were saved from stupidity and savageness by the long-continuing slowness of their mental emotions, and by their wonderful care of, and kindness to, each other.

We walked by their own way to the shore near us, and there I showed the Venuses the mystery of fire, and they were sufficiently civilised to wonder at and not worship it. They fed it with dry boughs, and hovered around it until I drew them away, that I might teach them the further wonders of fishing and cooking-not, indeed, those gaunt things like swimming bats or submarine devils which I had first seen when with Moxton and Weir, which seemed to go out in troops and move in squadrons like sensitive beings, but fine, scaly things with large swelling shoulders, and whose brain frame would scarce hold your little finger, and which jumped in ecstacy on a gaudy fly, and afterwards were led captives at will by a thread of silk. They evidently appreciated grilled-fish and fire, and would soon, I saw, be as completely civilised in these respects as the inhabitants of the earth.

Yes, my thoughts had already left my old home, and were clustering round these new creatures, thinking for them and of them whilst I knew the Star Climber was rushing through space with Weir and Moxton, and that millions awaited its coming with every variety of hope and fear; and that sweet girlmind, so full of wisdom and innocence, which had entered into companionship with mine and glorified it-and not it only, but to me all the future-was an eddy in the rising tide of thought. And these new creatures-I almost laughed as I looked at them-yet when they fanned their faces and gazed on me their idea again resumed its sway, their weight of individuality and character did away with the feeling of the grotesque which now and then began to rise up, and prompt me to surname them "The Happy Ogres," and dance around them like an unmitigated lunatic.

I think it must have been the overweight of thought-too much done, too much seen-for sometimes broke on me an awful desire, for sheer stupidity, to toss all thought and wisdom to the wind, and be a fool once more.

Driven by some such thought as this, I laughed right out as I looked on them, and then turned away and walked around them, as they sat on the bank of the lake watching the flickering sparks of the expiring fire, then came back 
and laughed again, and after that hardly felt safe from a wild spirit of facetious mockery and mimicry.

Yes, God knows the situation was thought-giving enough to an onlooker from the outer Heaven-the yellow sand, the broad sun, the two Venuses, dark and soft-furred, watching the expiring glow of the burnt wood. Great Nature's blessed peace lay on the woods and waters, and in the sunny air; yet they heeded it not, thought not of it-their hollow hands and soft bodies dabbled in the local warmth, all their thoughts intent and rapt amid the promethean spark. Nor did I, John Bentford Hope, care at all for Nature's beauty, though I saw and felt it-striding up and down on the hard sand, as careless of them or their thoughts as of the peace of nature-striding up and down by them, till I laughed aloud as one in madness at what I knew not, except that all things jarred and frayed, and roughened all my spirit, and the Venuses sat on without turning a thought or eye towards me or my wild motions.

\section{CHAPTER XVI.}

\section{Weir and moxton are stayed on their way by a meteor}

When Moxton and Weir left the planet Venus to reach once more the planet Earth they had a far longer journey before them than the previous one. They might, indeed, by waiting, have been borne into a corresponding position, but, with such an end accomplished, who would wait? Moreover, their greater speed would render their longer journey shorter in time, and as easily accomplished. There was no greater danger in the new route than the old, in both alike they might meet with wandering fragments-parts, yet outlaws, of the solar system-dangerous indeed for travellers. Yet, unlike those roving denizens of the old world, their danger did not increase with their size; when beyond a certain bulk their powers of gravity would prevent a collision.

In our first journey no meteor had rushed past us, nor had we been conscious of being touched by any mass, which was better than we expected, for, considering the immense number of small bodies that hourly fall to the earth, we thought-despite our lack of that all-potent attraction, gravity-that some stray fragment might dash itself to pieces on our sides, or pierce them like a cannon ball. So with greater confidence had Moxton and Weir set out on their homeward journey, and as they sped away their thoughts naturally turned backward to their friend left alone.

"Do you know? I pity him," said Weir, "with all he has done, and is likely to do, and we might say to be-still I pity him."

"Your pity need not be deep," answered Moxton, "take it farther back to those earlier discoverers-to Galileo and Columbus-and then Hope belongs 
to an older world, yet is one of this, and although he can never have the full confidence of fellowship which most of us enjoy, he has all the bright, social pleasures of companionship, and when Edith reaches him in his new world, time will not be dreary."

"Perhaps not," answered Weir, "yet I still say I pity him. I know it is something like pitying Romeo and Juliet; we woulld like to be one of them all the time. But just cast your thoughts back to John Hope on the planet, and then guess his thoughts from what they were before we left; he cannot help suspicion and dread; and I don't know, but I should not wonder at the frightful monotony of his life growing strong enough to bewilder his brain."

"You forget how much he has seen, and known, and even his fears and despairs are not much like monotony; besides, he may make some new discovery as startling as the two last."

"Which is the second?" asked Weir.

"Why, the road to the new world," answered Moxton.

"Yes, it does seem wonderful that after a man has outlived several generations, and taken such an acknowledged place in the world, he should elect to go on this wild voyage, and to stay on the other planet. But, at the same time, I think he is out of the road of discoveries now. What else is there to discover ?"

"You might have said that at any time in the world's history. Anyhow, he might find some reasonable inhabitants, and gain something from their experience."

"I think he would be more likely to find a reasonable animal. We did not see any signs of civilization except among the fishes. Yes; that is an idea. The towns and cities may be at the bottom of the sea, and Hope can employ his spare hours in finding out something that shall enable us to walk beneath the water without putting out our cigars. Yes, I can see something left for the future generations."

"Yes," answered Moxton, "look at the instruments and see how we are going."

"I will look, my good fellow," answered Weir, "but as you know, we with all our speed are ourselves the instrument obedient to every breath or atom that stirs in space; if they move we all move with them."

"I know," answered Moxton. "They have been completely stationary, but if you noticed, as we approached any object, there was a slight tremor about it, quite discernible."

"Yes, just as there is now," answered Weir, who was gazing on the delicate hands, just, perhaps, a shade paler than usual.

The mounting of nine days was as yet the account of their voyage, since the planet lay behind them, large and lustrous, and grew from an immense 
orb into a broad-faced horned moon, that hung far away behind them in the purple heaven, and their course had as yet been as steady as that of the sun in the heaven.

"Just as they do now," Weir had answered, and his face did most assuredly grow pale, and the spasm of fear, given and communicated, reached and spread round Moxton's soul. Their former voyage had given them too much confidence, that broad interstellar way had as yet no aërial lighthouse, no heavenly buoy, nought to mark or guide them from danger or death.

The million worlds and the myriad aerialites chased, and crossed, and followed each other in a tangled web, an endless range of contradictory figures, all scattered abroad in the great ocean of ether through which the Star Climber was ever rushing, "just as they do now," said Weir, and a real, a substantial shadow fell suddenly on them, the sunlight was blotted out. Each previous half-hour had their eyes-and then better eyes, their powerful glasses-swept all around the horizon; but behind them, the country from which they sped so swiftly, on that they had seldom looked; and from right above them or from beneath, might not a fierce meteor have been long rushing? Ah, they thought so now! Vast was the speed of the Star Climber, but might not some erratic fragment have a speed still vastly greater-hurled from the bosom of a monstrous volcano, whose pent-up pressure had consolidated diamonds, like mountains, and whose terrific discharge should leave the shattered ruby masses like an avalanche of loosened rock, and hurl outward fragments, large as little worlds, flying with all the speed of the parent orb, and all the mighty volcanic impetus superadded? Moxton and Weir thought of this now; to each other each one's thoughts were visible, and the great shadow was over them.

Shall we blame them, that they at this moment forgot the lessons of their previous voyages, forgot that omnipotent factor, gravity?-Forgot that it had some time ceased to keep up his steady pull on them and their belongings?

Shall we blame them that, springing as they thought to their posts of observation, they forgot their muscular power, and went with a bang against the ceiling, bounding and rebounding between that and the floor in dire and scrambling disorder? Shall we count the many seconds that passed ere their eyes could give tangibility to their fears? Ah! no, for in that latest instant as their glance sped outward, their hands turned to their instruments. But, ah! even then their fate was upon them. 


\section{CHAPTER XVII. \\ J. B. Hope on the planet.}

Hope left the two Venuses still on the beach, and sailed out in his boat on the lake down the long winding-like water. He did not care to return to his castle. The sight of their companionship awoke many memories of the world he had left. To have seen those two beings in their nest of moss and grasses, to hear the soft, low murmur of their voices as they seemingly grew quite unconscious of any onlooker, in their soft and lover-like play together! A gnawing sense of discontent had grown up in Hope's heart and he stayed with them no longer.

What was his life now? What was it worth, weighed in the balance of chance and fate? Those two beings, with scarcely a tenth of his knowledge, with scarcely a thought beyond themselves, were happier than he. What had it given him, all those far-reaching yearnings and strivings? What was the future to him, cut off by such an unfathomable ocean from that which had grown as dear as the light of heaven to his heart? he, whom a senseless wandering meteorite might exile for how long!_Ah, who could tell! — till he were trebly an outcast, till here, in this savage world, he grew to be as a beast among men. Yes; what were all his hopes and aspirations, his passion for progress, but the baits and bribes of the great source of life? Yes, and was not all the world drawn on like baby children, tempted by a present pleasure to fulfil an end of which they never thought?

Yes; we may flatter ourselves that we are gods-but why do we work and strive? That the life that grows up in aftertime may be moved, and pleased, and hallowed? No! but to fulfil an unsatisfied yearning that drives us remorselessly onwards, with as little thought of the end, the effect, as has the basest criminal giving way to his brute instincts. Truly, providence uses us very ill. Must we for ever toil on in the dark; must we be always as babies, coaxed with sugar plums? If life be so good, worth so much contrivance to keep alive, why cannot we grasp the Godlike end and pleasure, to fulfil which all these liquorice baits are held before our eyes? And why does the taste of pleasure beget in the nascent soul such a transformation and make each one follow the enchanter in wild route? Yes, providence takes us at the lowest valuation, and do we imagine it is wrong ? Let us enjoy ourselves as we are, and trust to the hands that stretch out from bright clouds to guide us onward!

John Bentford Hope was moving steadily across the bright water. His boat, brighter than that of the poet's fancy, sped on-not drawn by some unknown current, but impelled by the same silent, tireless power which could lift it up into the air and drive it along like a bird in the sunbeams. The boat sped on; the long, watery winding way was passed, and the open lake, with a rippling breeze, was before him. Hope stayed the machinery; the boat glided slowly; 
then he took a pair of sculls for the boat's sides and began to drive himself through the water.

For more than an hour he pulled; then resting and looking back, saw that he was not half way. But what of that? 'Twas not to cover space that he unshipped his oars. The swift blood pulsating through his veins seemed to have swept each deluding lie from his brain. He saw the great sun sinking in peace, his own shadow stealing out on the water; the light wind dropped, and all the sweet pleasures of a summer evening stole over the planet. One cannot always see visions and dream dreams, or, what is still better, see and know that which is more strange than a vision, more wonderful than a dream. No; but lapped in the soft air, with the water gently laving the sides of his boat, he could enjoy the peace and rest of nature; assimilate the wonders he had known, and wait for the coming hours with a bright hope. Yes; till all those glad faces should look again on him-till here, too, should reign the works of man, and this planet should teem with human pleasure. Then his boat, as if impelled by a similar thought, spread out its wings, and the Midge seemed, with a visible tremor, to long to dash away into space, to get nearer their native country.

Later in the evening, when Hope, like a giant of old retreated into his castle, letting fall the portcullis, and barring his windows, he began to think again of the two beings he had left.

How strangely had his thought and estimate of them altered since he saw them standing over him as he awoke from his dreams! Then they were angels or devils, satyrs or fawns, something more wonderful than man. How his heart throbbed at their touch, their gentle speech and manner hallowed them in his mind. And now it was reversed-far away were the gods and goddesses of divine and beautiful stature, of noble and great mind, of power and of beauty. "Yet," said J. B. Hope to his soul, "this is but the tide of emotion, and should my comrades be delayed on their voyage how much will this new race be to me? Does not a man forget his home and his friends for a dead and lifeless thing, for an invention, for a picture, for an idea new to art and science, and will not another race-a race not human, yet having those attributes which we conceive in themselves to be the essence of humanity-fill my mind and occupy my thoughts; yes, and despite their want of mechanical culture, take a high place in the temple of my spirit, where the image of each one I have ever known is set up in its appointed niche, and seldom moved from its first estate, though, perchance, often taken down and weighed in a more perfect balance? So will these two presently gain their rightful position. What shall I call each of them?"

Then he thought of their softness, their strength, their helplessness before the dictates of fate, and joining the outcome of thoughts past and present, he 
named them Philomenia and Hyperion, and resolved to teach them these titles even as he would learn their own names as soon as he could master their most strange speech. Would they not soon learn to trust him; in a few days ride with him in the Midge to the bounds of the world; show him their friends; and would he not learn as much as they knew themselves of their past history? And what might there not be in that land of mist and darkness, where for long months the wind never came, where a grey twilight fell always, and all nature under its influence seemed to grow strange and monstrous? They had traversed it in the Star Climber, they had walked about in its dim labyrinths, yet had seen, they knew, but spots; and then would not any living creature have fled from the coming of their vessel, as with its wondrous lights and powers it pushed through the dim air? Yes-even if there were no spirit of adventure among the Venuses, he would traverse and know this new world ere his friends returned. Yes; already he knew much; 'twas not a world of ocean and land, but of land and seas, or rather lakes, of high mountains and deserts. His mind reverted to their first landing, the immense waste they first rested in, and all that high barren land which lay around the northern pole of the planet, so high that it lifted itself up through the stratum of air, and to visit its wonders needed appliances as perfect as to leave the world. But it was not in these unknowable regions that J. B. Hope was interested. They had come to find a future home for the growing millions of their native earth, and here all around the tropical zone was a region fitted with everything necessary, while the dim polar regions would serve to exercise all the latent ingenuity of the coming man.

\section{CHAPTER XVIII.}

The meteor catches them-they go out.

It was not a planet, large or small, not even a moon, but as they afterwards found of mass ably sufficient to give them a gravitation force of five ounces.

Yet it was a huge meteor coming with immense speed, large enough had it met them to crush, as bullet is crushed on target, the Star Climber; large enough to take and carry them out on its own wild track, into the unutterable wilderness of space.

The little moon they had visited ere they had reached Venus, was a world, small perhaps; but this was but a lump, a patch, a huge curled and twisted mass of conglomerate, belched by some volcano into the outer air, a mass that would bury itself in an ocean should it ever strike a watery world, or crush a city, in a second of time, should it so happen. But, big or little, it grew out fast to their straining eyes. There was no rushing sound, not even a vibration to speak its coming, yet swiftly and inevitably it drew near. 
"It will pass us," said Moxton, and then with an awful suddenness it was on them-a frightful whirl of the Star Climber told them they were caught and carried away captive by it, saved indeed from any sudden catastrophe, but as they again resumed their stations they saw that the Star Climber was dashing like a mad thing around this wandering atom. Now they saw their fierce speed, as the huge rocks sped away beneath them; and so small was the thing that held them they could feel the circular motion, the swerve, as they were swung by the invisible chain. Only Moxton's presence of mind prevented them from meeting like a comet the attracting mass, and rushing off at an elliptical orbit, every step of which would have to be, with much loss of time, retraced.

His hand was already working the levers of their boat, the Star Climber's wings were spread abroad, and those on the outside were beating the meagre air that sailed with the wandering fragment; but that alone would never have altered our headlong course-a touch of the bearer-our rocket tubes wheeled their mouths towards our huge enemy and we were conscious of the increasing distance; they burst forth-the effect was instantaneous, the head of the Star Climber came to, and again we were rushing around a new world. But what a world? - perhaps three miles long and one at its central diameter. But even this must have some slight atmosphere, for we were beginning to feel a great glow of heat through our vessel, and as our wings were drooped to stay our course, we could hear a roaring like a distant waterfall.

Weir left his post of observation and stood near Moxton. The heat was growing oppressive to both.

"We will keep as close as we can," Moxton answered to Weir. "Look!" and indeed it was needful to use all their powers to keep close to this fragment of an orb-so great their pace and so small its gravity. Round and round it they sped, and were glad to perceive their speed decreasing, and the Star Climber coming once more under the influence of her wings.

There was a slight stratum of air lying in all the hollow or on the flat places, but up where its sides ran out into corners and sharp angles their course seemed as free as in space itself. They resolved to land and take a fresh departure for their home; also to survey this wandering star, and find its orbit and place, that they might not again fall into its power.

The Star Climber came to rest in a long, hollow valley covered with coarse, brown sand, which seemed to have come from the corroded rocks standing up here and there amongst it, some half buried and some lying loose as if scattered there yesterday, and away on the higher ground the clear-cut, cold masses were exposed bare to the surrounding heaven. 
Though they had been but ten days on their homeward journey they felt a great longing to tread on the solid ground once again, the long silent sandy slopes looked inviting, and all the higher rocks seemed to court investigation.

"Let us go out," said Weir, "if only for the fun of the thing."

Moxton agreeing, they prepared their air-pipe supplies-something like a bagpipe in appearance; they could breathe in the air through a mouthpiece and expel it through the nose. With these on they could walk in a vacuum for an hour or more.

The place where they rested was hidden from the sunbeams by a gradual rising of the ground, and Moxton suggested that Weir should step outside just to try the air and temperature.

"You can hold the door, you know, and all the thin air we get in will not hurt us."

The sliding doors were shot back and closed again behind them, then Weir opened the outer one and stepped out.

Moxton had not long to wait-the larger part of a minute, then Weir reeled in.

"What is it like?" asked his partner, as Weir panted for breath.

"What like? Well, get into an ice water bath, drink as much balloon gas as you can, and get some one to choke you, you then have an idea."

"Shall we go?"

"Oh! yes. I don't suppose it will be much worse than the shady side of the moon, and, thank heaven, it cannot blow."

"No, or it would send us into space. Don't fool about, Weir. I believe a good jump would send one clear altogether, most likely to grace this miserable fragment as a moon."

"Yes, what a fate for a bloated human, an attendant orb of the solar system, whose ambition could soar beyond. Mahomet's resting-place would be nothing to it."

"Cover up all but the eyes, Weir," said Moxton, as they were preparing.

"And those, too," answered that individual, coming out as he spoke, bound hand and foot, his glasses fastened tightly into the coverings of his face, so that the atmosphere could touch no part of his body.

Moxton followed his example; yet, ere they went, called again to Weir. "Look!" said he, putting his finger on a spring balance and lifting himself some eighteen inches from the ground.

"Yes, I see by the scale, five ounces. Well, as we have been used to weight nothing at all, we ought to get on first-rate."

So they went out together. 


\section{CHAPTER XIX.}

Hope goes with the venuses to find their home-some tigers fight.

Hyperion and Philomenia came and went freely between their own nest on the water and the dwelling place of Hope. They began to grow familiar with him and he with them. They did not show anything in their manners akin to reverence or worship; but, despite their uncouthness of aspect, they began to grow companionable. A certain individuality, probably born of long descent in a fixed type upheld and dignified them.

Unlike the enervated races of warm climes, they looked for no Avator to pour out unthinkable blessings; no Golden Age ever shone in their distant future. They seemed to take the present time and live and think from day to day.

Hope gathered from their signs and half-comprehended words that in a far off land dwelt a nation of such as they, a Venus people, but they seemed to fear to show the way to their native country, nor could he, after once understanding them, induce them to talk on the subject. But he did not despair at the first repulse, he knew they would grow to trust him, he knew that they would soon perceive how little chance their secret had against his wondrous powers of travelling.

Never were the Venuses so content as when in their boat or on their little raft. The mainland seemed to them forbidden ground, only to be visited when necessary, and then with care and caution.

Hope began to perceive how helpless they would be against the attacks of the fiercer of the wild beasts, who probably, from finding no equal in strength, developed prodigious, if brainless, courage.

When Hope met the Venuses in the morning it was his custom to shake hands with each. This seemed entirely ludicrous to the two Venuses, and there were generally three laughter-lit faces as Hope took between his fingers the end of Hyperion's huge, muscular arm, which, from its very conformation, was incapable of any motion save a smooth, undulating one.

Then the Venuses would insist on going through their code of salutationtheir long right arms would curl around Hope, then the smaller left arm would stroke in a soft, methodical manner. It usually ended by Hope's pressing his lips to Philomenia's face, which ceremony they seemed to understand, and to such an extent appreciate, that Hope had little doubt but that kissing might be easily introduced among the Venus nation.

The days, though few in number, seemed a long time to Hope, as though seasons had already passed since his comrades left him. It is ever thus. The dreary days of dull monotony appear when they are past as but an hour, while even minutes of intense feeling form often epochs in our existence. Thus it 
was with Hope, his long sleep was less than a dream, the hour of his awakening a whole lifetime of feeling. The many hundreds of hours passed in the Star Climber seemed now shorter than those fleeting seconds when he awoke and saw the Venuses.

But Hope wished to find out Venus land, and often importuned Hyperion and Philomenia to go thither, for, knowing them, he did not wish to go alone. He represented to them his power and skill, showed them the many ways in which he could aid and help, and, to accustom them to the swift motion and inure them to the new sensation, he would take them whenever they were willing short trips in his boat, the Midge.

One day Hope saw them conversing more earnestly together than was their practice, their faces betokening that some emotion stronger than usual was working within them. He grew anxious to know what would be the outcome. Nor had he to wait long, for they came to him and began to explain in their broken language that they wished to make some solemn covenant with him, and then show him Venus land. This was what he waited for and almost expected.

When they thought that he understood them they put each one their smaller arm around him and led him out of his castle till they were under the sky. Then they lifted up their right arms-huge limbs-pointing strangely to the heavens, and repeated words or made signs which, although Hope could not understand, he perceived were by them thought to be solemn and holy. At first he was quite silent, then, as they again repeated the same sounds and looked at him, and again at the sky, he perceived what they needed and tried to follow them. Perhaps he was not very successful, but his attempt pleased and tranquillized them. They loosed his arms and bowed themselves towards him, but something in their unarmed, comparatively helpless state, in their confidence and trust in him, touched Hope's heart. They would have gone at once to his aërial boat, but he stopped them. They turned and stood linked together, as was their wont, before him. Then he spread out his hands and laid one lightly on each shoulder, gazing into their calm inscrutable features, his eyes going from one to the other and finding the same deep wonder in each face, the same long, patient waiting in each one's eyes.

"Listen," he said. "As long as I am with you, no harm that I can prevent shall happen to you, neither will I now or at any other time see you wronged without striving to help you, and wherever your native home may be I will always hold it a sacred thing." He ceased speaking; he took his hands from their shoulders; his eyes turned from the sky to them again. Then they all three went to the boat together.

Where would be that land, hidden from all the rude air, a valley of Avelon, shut in by mountains and deep seas, a garden of Eden, a cradle for this 
human-like race? They were speeding swiftly over the wood and water and the finely variegated surface of the planet, bearing a little towards the warmer regions, sometimes following long, winding, slow-paced rivers, or going above the shores of seas, flitting swiftly and silently under the directions of Hyperion and Philomenia, at a pace, indeed, vastly slower than Hope himself would travel at, for the Midge was built but to carry one, or at the most two, and the extra power needed to sustain the greater weight was all taken from her speed. Yet although her speed was comparatively slow, it seemed at times too great for the slow-moving brains of the two Venuses. They could only, by stopping and reconnoitring the various landmarks, proclaim the way even in an indefinite manner.

So they sped along hour after hour, Hope ever anxiously expectant to see more of these strange people, for he had gathered from Hyperion and Philomenia that they were not the only Venuses who had left their natal home, though he thought, from all that he could glean, that the number who had left were few, nor had they been happy or successful in their migrations. He looked in vain for any sign of human sense, for any raft, or hut, erected like the one he knew on the waters, for any upright form moving beneath the branching trees or on the open plain.

Troops of beasts fled away beneath him, as when, with Moxton and Weir, he had sped around the planet, and again he saw the strange sight of a huge pack of tigers spread out like a company of skirmishers, driving back a small but formidable herd of buffaloes.

Hope stopped the Midge and hovered over them to see the end-and that was not long in coming. The buffaloes were between the forks of a large river, and must either fight or swim. Once or twice they rushed out in a troop and seemed inclined to charge their adversaries, but were evidently afraid. Then, as they entered the broken ground, their fierce foes moved up, swiftly and silently as perfectly trained soldiers, deepening not thickening their ranks, as the ground to be guarded became less. The buffaloes gavce a wild roar, half of rage and half of fear, as they saw their enemies coming nearer; then one of them leaped off into the water and swam down the stream for the other bank, all his fellows watching, even with their dull brains seeming to know his fate, for, as he neared the shore, Hope from his elevation could see three huge beasts creeping towards the spot where the buffalo would land. They allowed him to get half out of the water, then they flung themselves on him-his roar of pain being heard above the tigers' voices.

This incident was as the firing of the fuse is to the explosion; the whole of the tigers with a fearful cry rushed forward. Whether their fierce natures were roused by the cries of the strangling beast, or whether they knew that this would bring on the final rush of their victims, Hope could not tell; each and all 
seemed to move simultaneously. The buffaloes wheeled short round, and crushing themselves together dashed out at their foes, not singling them out individually, but evidently trying to go through them. Nor were the tigers eager to meet their direct charge, escaping often by a tremendous spring at the last moment, or, when too much before the centre of the herd to escape, bounding with a sure aim upon the back of one of the foremost. Meanwhile, like a troop of horses, from each side the tigers dashed in on the flanks at this forlorn hope. For a moment Hope thought some of the foremost would by their speed escape; but this was not to be. He already saw dashing across at a short angle about a dozen tigers which had evidently not gone far in the first rush. The three leaders, which were all that escaped the first slaughter, gave a great helpless roar as they saw their foes again upon them, then they sank to the ground beneath the teeth and claws of the victors, and as the last one fell Hope saw one of the tigers go out from the others on to a little rising ground and then give a loud, far-sounding cry-and from the side of the water and far back in the broken ground there appeared tigers answering the voice and coming to the slaughter.

\section{CHAPTER XX. \\ Exploring the wonder.}

Weir and Moxton descended from the port of the Star Climber, and stepped out on to the surface of the meteroic mass on which their vessel now rested. It would be very safe to say that no living foot ere this had ever trodden this fragment of a world; the brown sand despite their light weight seemed like quicksilver about their feet, shifting, and seemingly flowing in an unnatural manner. Overhead stretched an inky purple sky, pierced with pale points of light, little, faint white stars. The sun was hidden from them, and the planet they had left shone like a miniature moon-a pale crescent. In the far far distance, no life or sign of life was near them. Through all their wraps they felt the penetrating cold, they realized perhaps for a second their intense isolation, their wondrous solitude, their seemingly perilous position-going away through space on a desolate frozen fragment, being carried they knew not whither, and between them and their fate stood but their aërial boat, the Star Climber. They were looking at her now, her blackened blistered sides, her frayed and folded pinions. Moxton drew out the point of one of them, it was the same as when they left Venus; nothing had harmed the vessel since she had passed through the Magellan cloud. They walked round her, and Moxton, going up to her prow, taking the rise of her keel in his hands, found that he could with ease lift or move her hundred tons of weight. The strangeness of all things seemed to grow on them, the thin air caused every 
fluid and solid in their bodies to swell and dilate, their skins grew tight, a sensation of puffiness pervaded and grew on them, their brain seemed to wander, their thoughts grew vague and uncertain, nothing seemed of the least consequence; it was as though they had drunk some ethereal champagne, and scarcely knew whether they were wandering atoms, whose home was space and whose meat and drink the thin air that stretched from star to star, or human beings who needed warmth, and food, and covering.

They knew themselves to be walking as men in a dream, beset with dangers which they could not realize. Yet in spite of all this, in spite of the uselessness of their undertaking, they both determined to perservere and fulfil the programme they had mentally sketched ere leaving the Star Climber.

They had intended to walk away across the sandy valley up to a ridge of rocks about half a mile distant, from which they would be able to survey at least one half of the body they were standing on.

Weir touched Moxton, who turned towards him. He took his arm and they strode away together.

As they ascended the rising ground, which had cast a shadow over them, they felt the warmth increase sensibly. The dry sand and rocks caught and retained the radiant heat, and made them well-nigh comfortable, could they have got rid of that strange, swollen, drunken-like feeling which possessed them, but this they felt to be increasing, as they hurried on to reach the rising ledge which was before them.

The soft sand yielded and flew away behind them as from the feet of an ostrich, and their stride, ostrich-like, with the least exertion carrying them many more yards than on either planet they could compass feet, brought them quickly to their destination-but not too soon. Weir was already feeling more and more uneasy; the thin air seemed mixing with their blood, and working down into the capillary tubes of their veins, though in truth it was not what they swallowed but its effects on their exterior parts which was now troubling them. Weir's fingers amid their thick wraps seemed like huge rigid bars, feeling to him more like the claws of the devil in some mediaeval painting than aught else that can be imagined. Moxton too, was suffering, but more from light-headedness. Curiosity, however, and a certain stubbornness, impelled them both to try and complete what they had mentally planned ere they left the Star Climber's shelter.

But what a sight awaited them! This must surely be the very spot where Milton's devils fell—with hideous ruin and confusion-down; only the bright sun never shone there, for now beneath them was a clear precipice, not of hundreds or thousands of feet, or miles, but down, down, down beyond the lower edge of the world, and still on. The only thing that broke the dream was the vision of stars far away in the immense depth below, which the mile of 
barren rock seemed to emphasise-to make space gape like the mouth of hell, till to the disordered imagination those pale points of light might seem starry gleams from the great charnel house which old-world fables have built below.

The thin air seemed to have lifted from the brain of Weir and Moxton that rich harvest which the past centuries had so abundantly borne. The solid truths and fruitful facts which have so cheered ripening manhood on its way, seemed to have ascended from their brain, and from its deeper recesses arose unbidden a host of those wild thoughts which made men or women angels or devils, and drove humanity mad; their imaginations raced away and their fancies ran riot amid monstrosities as strange as any mediaeval legend. Had some fiend descended before them, they would scarce have wondered; had some aged Satyr or unlovely Faun accosted them they would not have been surprised; and then, they felt themselves to be so light, so pitiably unstable, ah! far lighter than those poor ghosts whom Dante saw driven before the more than pitiless blast!

It may be that gazing down into that immense depth affected their already benumbed brain, as a nightmare does, or as rushing water or a steep place affects the would-be suicide. They sat down on the gray rocks that were scattered around, and tried to collect their thoughts, their eyes wandering once more over the weird landscape. Away in the valley lay the Star Climber, black and sere, a ghostly-looking craft, the wan sun, the faint stars, the dark sky, the crumbling rocks, the loose sand-all melancholy and unnatural, as of a world in its dissolution. Yet, as they rested, their senses returned to them somewhat, and they determined to take one more look over the precipice and then return to their vessel.

They climbed on to a projecting part of the ridge, where the rocks overhung many feet, and as they gazed down the same mad thought occurred to each, namely, to cast down the cliff one of the loose rocks. 'Twas little more than the gratification of a childish whim, and Weir was naturally the more eager to fulfill it. 'Tis probable some secondary thoughts occurred to both as to how the powers of gravity would deal with the falling mass, yet their main idea was but to see a mass of rock fall clattering into the void of space. Weir was searching along the cliff trying each rock till he came to a loose one, then he nodded to Moxton to watch the effect, and with both his hands gave it a heavy push. With a dull rumble it gave way and launched itself into space-but not alone; rooted like a giant tooth along the ridge of the precipice, the huge fang had risen beneath Weir and tossed him far into space.

Moxton was transfixed that instant. Weir's fall renewed all the horrors of imagination, and paralysed his friend's mind. 
Weir weighed five ounces, and the rock perhaps a thousand times as much. The impetus he gave it, unchecked by any appreciable gravity, had tossed him far into space. Moxton saw him with arms wide-spread falling, falling and turning-good God! Would he never cease to fall? The huge rock fell and struck, and fell again-but Weir out in space. Moxton thought his brain would burst. Would Weir never cease to fall?

\section{SWIFT FALLS THE CLOUDY CURTAIN}

Swift falls the cloudy curtain,

The rain comes down amain,

The wild wind echoes deathfully

Across the midnight plain.

Darkness and dreary tempest

Blot out all hope of light.

No dream of joy or gladness

Breaks through the dull hours' flight.

High in a dim room lying,

Is a maid sick unto death;

She hears the wind's voice crying

With hopeless, helpless breath.

Pale_pale and sick all nature;

Weary both walls and blinds;

Helpless the eye that looks adown,

And the face she never finds.

Pale-pale and sick all nature-

All things that round her lie;

And no hope in her anguish,

For to-morrow she will die.

\section{LOVE SONG}

Daintily, O! daintily,

So daintily she goes;

Day's uncertain, night is nothing;

Time, a very wind that blows.

Wishful Eden, bless'd minute,

Can I ever linger near?

Dies the crowd's uncertain murmur

In my heedless, drunken ear. 
Tell of voices, tell of breezes,

Noise of brooks in desert lands;

Dream, that thirsty wanderer pleases,

Stretched upon the shadeless sands.

But that voice by love enchanted,

Steals, ah! floats into my soul,

Wordless rapture, speechless feeling,

O'er my heart from pole to pole.

[These two poems occur, without any introduction or attribution of authorship, on pages 39 and 40 respectively of this volume of The Great Romance. There is no indication of how they are intended to relate to the prose work. The first volume also contained verse, in the form of a dedication to John Keats.] 